\title{
Expression of a Missense Mutation in the Messenger RNA for $\beta$-Myosin Heavy Chain in Myocardial Tissue in Hypertrophic Cardiomyopathy
}

\author{
M. Benjamin Perryman, Qun-tao Yu, Ali Jalilian Marian, Adolph Mares, Jr., Grace Czernuszewicz, Jonah Ifegwu, Rita Hill, \\ and Robert Roberts \\ Section of Cardiology, Baylor College of Medicine, Houston, Texas, 77030
}

\begin{abstract}
We have determined that a missense mutation in exon 13 of the $\beta$-myosin heavy chain ( $\beta \mathrm{MHC}$ ) gene is expressed in the messenger RNA (mRNA) isolated from a right ventricular endomyocardial biopsy obtained from the proband of a family with hypertrophic cardiomyopathy. The mutation is the result of a substitution of an adenine for a guanine residue in one allele of the $\beta \mathrm{MHC}$ gene and creates a second recognition site for the restriction endonuclease Ddel in exon 13. The mutation is inherited in a Mendelian fashion and co-segregates with hypertrophic cardiomyopathy in this family. Complementary DNAs synthesized from RNA isolated from the endomyocardial biopsy were cloned into a plasmid vector and sequenced to confirm the expression of both the normal and mutant allele in mRNA of myocardial tissue. This is the first report of the transcription of a mutant $\beta M H C$ gene allele into mRNA of the myocardium. ( $J$. Clin. Invest. 1992. 90:271-277.) Key words: hypertrophic cardiomyopathy $\bullet$ molecular genetics $\bullet$ mutation $\bullet \beta$-myosin heavy chain
\end{abstract}

\section{Introduction}

The first primary cardiomyopathy due to an inherited defect for which the gene has been identified is hypertrophic cardiomyopathy (HCM). ${ }^{1}$ The disease is inherited in an autosomal dominant manner and the putative disease gene is $\beta$-myosin heavy chain $(\beta \mathrm{MHC})$ located on chromosome 14(1-4). Several mutations have been identified in the $\beta \mathrm{MHC}$ gene of affected individuals (5-9) and shown to follow Mendelian inheritance. $\beta$-myosin heavy chain is expressed in cardiac (10) and skeletal muscle (11) and is the predominant myosin in cardiac tissue. HCM is manifested as a myriad of clinical features including sudden death, heart failure, syncope, and angina with underlying pathology of left ventricular hypertrophy $(12,13)$. Thus,

Address reprint requests to Dr. Roberts, Section of Cardiology, Baylor College of Medicine, 6535 Fannin, MS F905, Houston, TX 77030.

Received for publication 13 January 1992 and in revised form 6 March 1992.

1. Abbreviations used in this paper: HCM, hypertrophic cardiomyopathy; $\beta$ MHC, $\beta$-myosin heavy chain; PCR, polymerase chain reaction; $\mathrm{RT}$, reverse transcription.

J. Clin. Invest.

(C) The American Society for Clinical Investigation, Inc.

0021-9738/92/07/0271/07 \$2.00

Volume 90, July 1992, 271-277 responsible for such a varied phenotype particularly inasmuch as early studies on the $\beta \mathrm{MHC}$ protein from patients with $\mathrm{HCM}$ show the protein to be normal as determined by conventional techniques $(14,15)$. Although studies to date have shown the $\beta$-myosin mutations to be present in genomic DNA (16), it remains to be determined whether the defect is expressed in the tissue primarily responsible for the phenotype, namely, the cardiac myocyte. Documentation of the myosin mutation transcribed into the cardiac mRNA is an essential first step in determining whether the defect is responsible for the disease. Accordingly, the present study was performed to determine whether a mutation in $\beta \mathrm{MHC}$ gene identified in a family affected with HCM is transcribed into the mRNA of the cardiac myocyte. In a family of 11 individuals (excluding spouses), six of which are affected with HCM, we have shown that the DNA of the proband and affected individuals have a missense mutation in which adenine substitutes for guanine resulting in the substitution of glutamine for arginine in $\beta \mathrm{MHC}$. The substitution of adenine for guanine in exon 13 of the $\beta \mathrm{MHC}$ gene creates a second recognition site in the exon for the restriction endonuclease Ddel. Biopsy specimens of the heart were obtained from the proband and a portion of the $\beta$ MHC mRNA flanking the exon 13 mutation was converted to cDNA by reverse transcription and amplified using polymerase chain reaction (PCR). The amplified product was digested with Ddel restriction enzyme and both the normal and the mutant allele were found to be expressed.

\section{Methods}

Patient selection. Patients were diagnosed with HCM by using the echocardiographic criteria defined as the presence of septal or ventricular hypertrophy with a wall thickness of $13 \mathrm{~mm}$ or more in the absence of other potential causes of hypertrophy such as hypertension (2). All procedures and protocols used in the evaluation of each subject were approved by the Institutional Review Boards of The Methodist Hospital and Baylor College of Medicine. The pedigree referred to as number 155 was established and each family member was evaluated after informed consent was obtained. In the case of the proband, a right ventricular endomyocardial biopsy was collected after informed consent was obtained.

Lymphocyte transformation and DNA isolation. Blood samples were collected from all family members of pedigree 155, DNA was extracted for immediate analysis, and the lymphocytes were isolated for subsequent transformation. The procedure used to transform lymphocytes for subsequent DNA isolation has been reported previously (17). Lymphoblastoid cell lines were established on each member of Family 155 . Genomic DNA was isolated using an automated nucleic acid extractor (model 340A, Applied Biosystems, Inc., Foster City, CA). Isolated DNA was resuspended in a final concentration of 300 $\mathrm{ng} / \mu \mathrm{l}$ in $10 \mathrm{mM}$ Tris- $\mathrm{HCl}(\mathrm{pH} 7.5)$ and $1.0 \mathrm{mM}$ EDTA (pH 7.5). 
Amplification of exon 13 of $\beta M H C$. The gene for $\beta \mathrm{MHC}$ was amplified in the region of exon 13 by PCR. Cloned wild-type genomic DNA in the regions of $\beta \mathrm{MHC}$ exon 13 and the cloned mutant allele in the same region containing the exon 13 missense mutation from a patient with HCM were kindly provided by Dr. Christine Seidman (Harvard Medical School, Boston) and were used as controls in all PCR and digestion reactions (6). Primer sequences were designed (18) by using the published $\beta \mathrm{MHC}$ gene sequence (19) and are as follows: Sense- 5 'CTCTTACCAACTTTGCTCTTGC 3'; and antisense-5'CTGCTGGACATTCTGCCCCTTGG3'. The sequence of the sense primer was designed to be complementary to a sequence in intron 12 located $35 \mathrm{bp}$ upstream from exon 13 and the antisense primer complementary to a sequence at the $3^{\prime}$ end of exon 13 . Primer oligonucleotides were used at a final concentration of $0.2 \mu \mathrm{M}$. The PCR reaction mixture contained $10 \mathrm{mM}$ Tris- $\mathrm{HCl}$ (pH 8.3), $50 \mathrm{mM} \mathrm{KCl}, 0.001 \%$ (wt/vol) gelatin, 1.5 $\mathrm{mM} \mathrm{MgCl}, 200 \mu \mathrm{M} 4 \mathrm{dNTP}, 1 \mathrm{U}$ Thermus aquaticus DNA polymerase $(5,000 \mathrm{U} / \mathrm{ml}$; Pharmacia, Inc., Piscataway, NJ) and $250 \mathrm{ng}$ of genomic DNA per $25 \mu \mathrm{l}$ of reaction volume. DNA amplification was performed in a DNA thermal cycler (Perkin-Elmer Cetus, Norwalk, CT). The DNA was initially denatured at $94^{\circ} \mathrm{C}$ for $3 \mathrm{~min}$ followed by 30 cycles of amplification according to the following protocol: denaturation at $94^{\circ} \mathrm{C}$ for $1 \mathrm{~min}$, annealing at $57^{\circ} \mathrm{C}$ for $30 \mathrm{~s}$, and extension at $72^{\circ} \mathrm{C}$ for $30 \mathrm{~s}$.

PCR products were separated by gel electrophoresis in $2 \%$ NuSieve agarose (FMC Bioproducts, Rockland, ME) in buffer ( $50 \mathrm{mM}$ Tris, 50 $\mathrm{mM}$ boric acid, $1 \mathrm{mM}$ EDTA) at $100 \mathrm{~V}$ for $2 \mathrm{~h}$. The exon 13 fragment was isolated and extracted from the gel using a Sephaglas BandPrep kit (Pharmacia, Inc.). One-fourth of the volume containing the eluted product was used for PCR reamplification using conditions and parameters identical to those described above. The reamplified PCR product was extracted and isolated according to the procedure outlined above. The PCR product (exon 13) was suspended in $20 \mu \mathrm{L}$ of Tris-EDTA buffer and digested with the restriction endonuclease Ddel (48 $\mathrm{U})$ at $37^{\circ} \mathrm{C}$ for $2 \mathrm{~h}$. The products of digestion were separated and identified by ethidium bromide staining after electrophoresis in a 3\% agarose gel in Tris-boric acid-EDTA buffer at $100 \mathrm{~V}$ for $2 \mathrm{~h}$.

To determine whether in fact the PCR procedure was specifically amplifying exon 13, the identical protocol was performed on known normal (individuals unaffected with HCM) DNA. Normal genomic DNA was amplified in the region of exon 13 using parameters identical to the procedure used above for DNA amplification from members of pedigree 155. The amplified product of the normal controls was isolated, extracted and subjected to digestion with the restriction endonucleases Rsal and Ddel as described above.

Amplification of $\beta M H C M R N A$ from cardiac tissue. A right ventricular endomyocardial biopsy was obtained from the proband of family 155. The endomyocardial tissue was frozen rapidly in liquid nitrogen for storage at $-135^{\circ} \mathrm{C}$. The tissue was quickly thawed and homogenized by means of standard methods at room temperature for total RNA isolation (RNAzol method, Cinna/Biotecx Laboratories, Houston, TX) (20). The homogenate was extracted with chloroform and total RNA was precipitated in isopropanol and stored at $-20^{\circ} \mathrm{C}$ overnight. The precipitate was isolated by centrifugation and washed twice in $75 \%$ ethanol. The pellet was gently lyophilized and resuspended in $20 \mu l$ of sterile diethyl pyrocarbonate deionized water. Approximately $0.2 \mu \mathrm{g}$ of total RNA was extracted from a single endomyocardial biopsy sample and reverse transcription (RT) for the synthesis of the first strand cDNA were performed using $50 \mathrm{ng}$ of the total RNA, utilizing an antisense primer to exon 16 (5'ATCATCGATGTCCCTTTTGAGCTCTGAGCACTCATCTTCC $3^{\prime}$ ), by standard methodology (21). The conditions of the RT reaction were as follows: $50 \mathrm{ng}$ of the total myocardial RNA was added to $2 \mu \mathrm{l}$ of reverse transcription buffer $(5 \times$ HRT buffer [ $250 \mathrm{mM}$ Tris- $\mathrm{HCl}$, pH 8.3 at room temperature, $375 \mathrm{mM} \mathrm{KCl}$, $15 \mathrm{mM} \mathrm{MgCl}_{2}$ ], Gibco BRL, Gaithersburg, MD), and $1.5 \mu \mathrm{l}$ of the 10 $\mu \mathrm{M}$ antisense primer to exon 16 in a total volume of $10 \mu \mathrm{l}$ and denatured for $5 \mathrm{~min}$ at $85^{\circ} \mathrm{C}$. RT was accomplished by adding $1 \mu \mathrm{l}$ of RT buffer, $1.5 \mu \mathrm{l}$ of $0.1 \mathrm{M}$ dithiothreitol, $1.5 \mu \mathrm{l}$ of $10 \mathrm{mM} 4 \mathrm{dNTP}, 0.5 \mu \mathrm{l}$ RNasin (Promega Corp., Madison, WI) and $100 \mathrm{U}$ Moloney murine leukemia virus $\mathrm{RNase} \mathrm{H}^{-}$reverse transcriptase superscript (Gibco BRL) in a total volume of $15 \mu \mathrm{l}$. The final concentration of antisense primer and $4 \mathrm{dNTP}$ in the mixture was $1 \mu \mathrm{M}$ and $1 \mathrm{mM}$, respectively. The reaction was incubated at $42^{\circ} \mathrm{C}$ for $2 \mathrm{~h}$ and was terminated by heat inactivation at $68^{\circ} \mathrm{C}$ for $20 \mathrm{~min}$.

The cDNA sequence was deduced from the genomic DNA sequence for MHC (18). Primers were constructed to encompass the region corresponding to regions within exons $12-14$ of the cDNA. The sequence of the sense primer was designed to be complementary to exon 12 , (.5'GAGGATCCCTCCATGTATAAGCTGACAGG3'), and that of the antisense primer (5'TTAAGCTTTCTCCAGGGTGGCATTGATGCG3') to exon 14; BamHl and Hindlll restriction sites were incorporated at the $5^{\prime}$ end of the sense and antisense primers, respectively.

The RT product was diluted 1:4-fold with $1 \times$ PCR buffer [ $50 \mathrm{mM}$ $\mathrm{KCl}, 10 \mathrm{mM}$ Tris- $\mathrm{HCl}\left(\mathrm{pH} 9.0\right.$ at $\left.25^{\circ} \mathrm{C}\right), 1.5 \mathrm{mM} \mathrm{MgCl}_{2}, 0.01 \%$ gelatin (wt/vol) $0.1 \%$ Triton X-100, Promega Corp.] and was amplified by PCR (RT-PCR). $12.5 \mu \mathrm{l}$ of the diluted RT product was added to $12.5 \mu \mathrm{l}$ of PCR mix which contained $0.2 \mu \mathrm{M}$ sense primer, $0.2 \mathrm{mM}$ dNTP, $1 \mathrm{U}$ Taq DNA polymerase (Pharmacia, Inc.), resulting in a final concentration of $0.1 \mu \mathrm{M}$ sense and antisense primers and $0.2 \mathrm{mM} \mathrm{dNTP}$. Cycling parameters for PCR were $95^{\circ} \mathrm{C}$ for $3 \mathrm{~min}$ for one cycle followed by 35 cycles of $94^{\circ} \mathrm{C}$ for $1 \mathrm{~min}, 55^{\circ} \mathrm{C}$ for $1 \mathrm{~min}, 72^{\circ} \mathrm{C}$ for $1 \mathrm{~min}$, and a final extension time of $4 \mathrm{~min}$ at $72^{\circ} \mathrm{C}$. The PCR product was separated by gel electrophoresis on a $2.5 \%$ low melting point agarose gel.

The product was excised from the gel and digested by Ddel. The digestion was performed in a total volume of $60 \mu \mathrm{l}$ using the conditions outlined previously for the digestion of the PCR product of exon 13.

Radiolabeling and electrophoresis of the Ddel digestion products. The amplified cDNA product was digested by Ddel and labeled with ${ }^{32} \mathrm{P}$ at the $5^{\prime}$ end using standard methodology (22). Final reaction conditions included $50 \mathrm{mM}$ Tris- $\mathrm{HCl}(\mathrm{pH} \mathrm{7.6)}, 10 \mathrm{mM} \mathrm{MgCl}, 15 \mathrm{mM}$ dithiothreitol and $10 \mathrm{U}$ Polynucleotide Kinase (Pharmacia, Inc.) in a total volume of $30 \mu \mathrm{l}$ at $37^{\circ} \mathrm{C}$ for $45 \mathrm{~min}$. The reaction was terminated by heat inactivation at $65^{\circ} \mathrm{C}$ for $10 \mathrm{~min}$. The products were precipitated by ethanol using standard methods and lyophilized. The pellet was resuspended in $20 \mu \mathrm{l}$ of sterile, deionized water and an aliquot was electrophoresed on a $6 \%$ polyacrylamide gel for $75 \mathrm{~min}$. The DNA marker $\lambda \varnothing \mathrm{X} 174 \mathrm{Hinfl}$ was labeled at the $5^{\prime}$ end with ${ }^{32} \mathrm{P}$ and used as a size standard.

Cloning and sequencing. As a result of incorporation of restriction sites at the $5^{\prime}$ end of the primers, the 321-bp RT-PCR product contained BamHl and Hindlll restriction sites at ends. The RT-PCR product was digested with the above enzymes and purified using a Centricon 100 ultrafiltration system (Amicon Corp., Danvers, MA). The purified product was cloned into a pGEM vector and the recombinant DNA was purified and sequenced by the dideoxy sequencing method using a T7 sequencing kit (Pharmacia, Inc.).

\section{Results}

Studies were performed on a family (pedigree 155) consisting of 15 individuals including spouses. The proband had the clinical features of HCM and left ventricular hypertrophy was confirmed by two-dimensional echocardiography and shown to satisfy the diagnostic criteria as previously described (2). The mutation, a substitution of adenine for the guanine residue, results in the creation of a second recognition site for Ddel restriction endonuclease in the mutant allele. The DNA analysis was performed using PCR to amplify exon 13 followed by digestion of the amplified product with the restriction endonuclease Ddel. The synthetic oligonucleotides used for PCR analysis were selected to amplify exon 13 sequences between nucleotides 8744 and 8897 of the $\beta$ MHC gene. After PCR amplification the 154-bp DNA products were separated by agarose gel electrophoresis and extracted from the gels for digestion with 


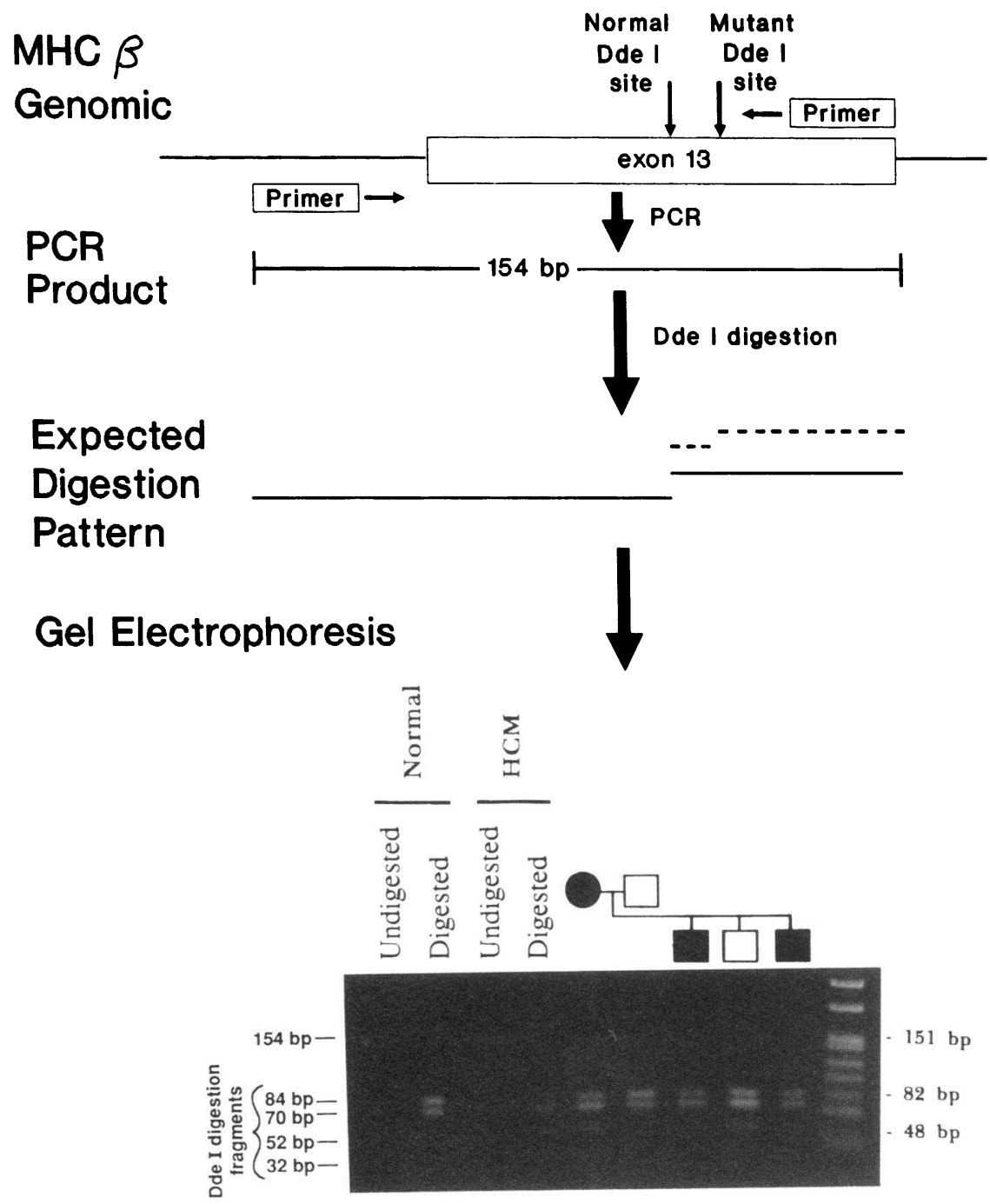

Figure 1. A schematic diagram of the relative locations of the normal and mutant Ddel restriction sites in exon 13 of the $\beta \mathrm{MHC}$ gene is shown in the upper portion of the figure. The 154-bp PCR product and the relative size of the nucleotide fragments produced after digestion of this product with Ddel are also depicted. The lower portion of this figure is a photograph of an ethidium bromide-stained agarose gel. It illustrates the electrophoretic pattern of the PCR product (exon 13 of the $\beta \mathrm{MHC}$ gene amplified from DNA of members of Family 155) after digestion with Ddel restriction endonuclease. Lane 2 is wild-type exon 13 DNA digested with Ddel and shows two fragments of 84 and $70 \mathrm{bp}$; lane 4 is exon 13 DNA from the mutant allele cloned from a patient with $\mathrm{HCM}$ and known missense mutation digested with Ddel and shows three fragments of 70,52 , and $32 \mathrm{bp}$. Exon 13 PCR product from a normal individual (containing two normal alleles) after digestion with Ddel shows two fragments of 84 and $70 \mathrm{bp}$ and exon 13 PCR product from affected individuals (containing one normal and one mutant allele) shows four fragments of $84,70,52$, and $32 \mathrm{bp}$. The individuals from pedigree 155 are indicated above the appropriate lanes. Size standards are in the extreme right lane and undigested and digested PCR products from a normal individual and the cloned missense allele are labeled Normal and HCM, respectively.

Ddel endonuclease. DNA template isolated from normal individuals produces two DNA fragments of 84 and $70 \mathrm{bp}$ when analyzed by this procedure. DNA isolated from an individual with the missense mutation, however, produces four fragments of $84,70,52$, and $32 \mathrm{bp}$ in that both the normal and mutant allele are present (Fig. 1). Genomic DNA analysis showed the proband to have a missense mutation in exon 13 of the $\beta \mathrm{MHC}$ gene and all three children of the proband were positive for the missense mutation while DNA from the unaffected husband was normal (Fig. 1). Two of the children exhibited clinical features of HCM, whereas the third child, also with the mutation, exhibits no clinical features of HCM. However, he is only $11 \mathrm{yr}$ of age, and because symptomatology is often not evident until later in life, it is premature to make a definitive diagnosis.

To determine if the mutation is expressed as mRNA in myocardial tissue, RNA was isolated from a right ventricular endomyocardial biopsy obtained from the proband of family 155 and was used as a template for RT-PCR. The cDNA was synthesized using an oligonucleotide primer from exon 16 for first strand transcription and nested oligonucleotide primers located in exons 12 and 14 for cDNA amplification. The expected $321 \mathrm{bp} \mathrm{RT-PCR} \mathrm{product} \mathrm{was} \mathrm{produced} \mathrm{from} \mathrm{RNA} \mathrm{tem-}$ plate isolated from myocardium of an unaffected individual and that of the proband as shown in Fig. 2. Genomic DNA template isolated from the proband produced the expected 872 bp (Fig. 2) product due to intronic sequences not present in the mRNA template. In lanes 3 and 4 , there are low molecular weight nonspecific PCR products. To ensure that the nonspecific products do not interfere with subsequent studies, the 321 bp product was excised from the gel and purified as described above and digested with Ddel restriction enzyme. The restriction fragments were 5 end labeled with ${ }^{32} \mathrm{P}$ and electrophoresed on acrylamide gels. The resulting autoradiogram and a schematic drawing illustrating the results are shown in Fig. 3. Digestion of cDNA from normal myocardium would be expected to produce two restriction fragments of 181 and $140 \mathrm{bp}$, whereas digestion of cDNA produced from RNA isolated from the myocardial biopsy of the proband produces fragments of 181 , 140,149 , and $32 \mathrm{bp}$ in length due to the expression of both the normal and mutant allele (Fig. 3). The latter cDNA restriction fragments from the proband result from the transcription of a second Ddel restriction site in mRNA corresponding to the missense mutation in exon 13 of the $\beta$ MHC gene. To confirm the location of the mutation in the cDNA both the normal and mutant RT-PCR products were cloned into a pGEM vector for nucleotide sequence analysis. Sequence analysis of the normal allele shows a guanine residue in position 1208 while an adenine residue replaces guanine at this position in the mutant allele creating an additional Ddel restriction site (CTCAG) (Fig. 4). 

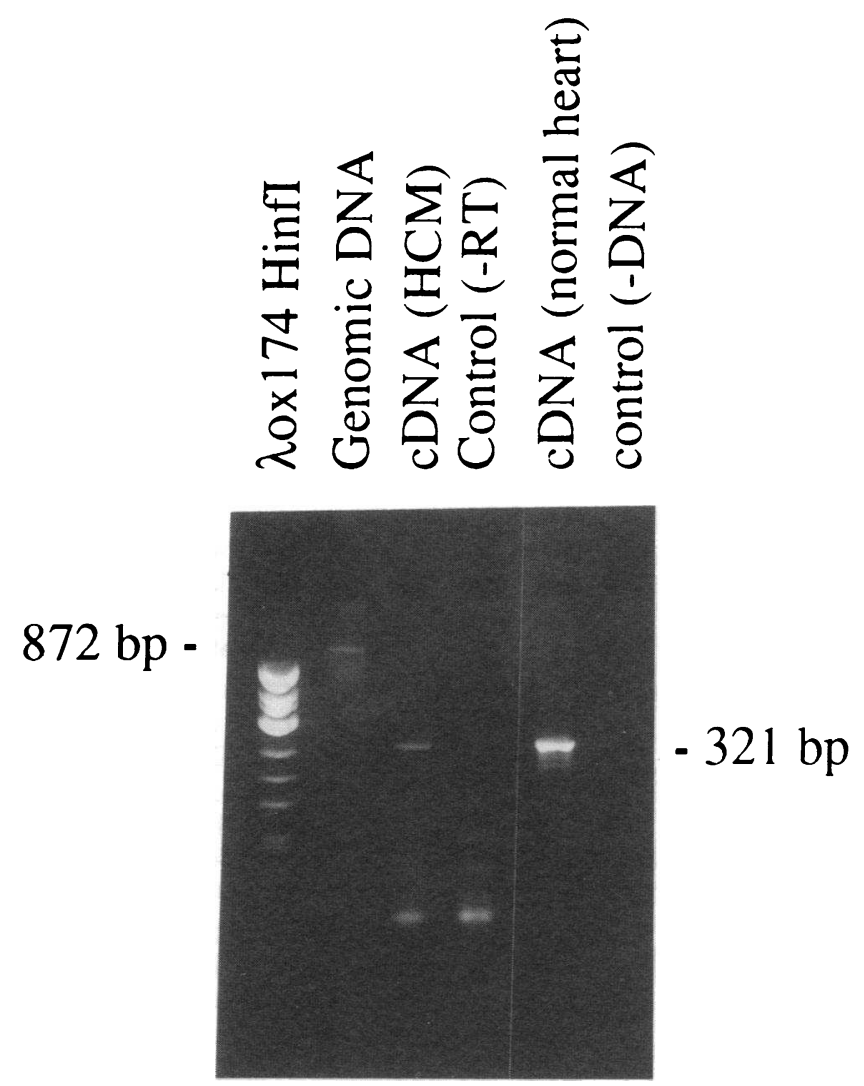

Figure 2. Photograph of an ethidium bromide agarose gel of the cDNA products produced by RT-PCR of RNA isolated from an endomyocardial biopsy from the proband of Family 155 . The cDNA product produced from the proband is labeled $c D N A$ (HCM), the cDNA product produced from a normal heart is labeled $c D N A$ (normal heart-explanted hearts of the patients undergoing cardiac transplantation for ischemic heart disease), the RT-negative control reaction is labeled Control $(-R T)$, the PCR control reaction product is labeled control (-DNA), and the PCR product obtained using DNA as the template is labeled Genomic DNA. In lanes 3 and 4 there are low molecular weight PCR products. To ensure that the nonspecific products do not interfere with subsequent studies, the 321-bp product was excised from the gel and purified as described above and digested with Ddel restriction enzyme. The molecular size standards are in the far left lane.

\section{Discussion}

We have determined that a missense mutation in exon 13 of the $\beta \mathrm{MHC}$ gene is expressed in the mRNA isolated from a right ventricular endomyocardial biopsy obtained from the proband of a family (pedigree 155) with hypertrophic cardiomyopathy. The mutation, which was first shown to be inherited in a Mendelian fashion in a large French-Canadian family (6) and more recently in others (9), is the result of a substitution of an adenine for a guanine residue in one allele of the $\beta$ MHC gene which creates a second recognition site for the restriction endonuclease Ddel in exon 13 of the gene. The mutation is inherited in a Mendelian fashion in family 155 and co-segregates with the inheritance of hypertrophic cardiomyopathy. One son with the mutation (see Fig. 1) although normal by clinical and echocardiographic criteria is only $11 \mathrm{yr}$ of age and thus is at high risk for developing symptomatology later in life since age-depen- dent penetrance is felt to be characteristic of hypertrophic cardiomyopathy (23).

The missense mutation in exon 13 presumably results in the substitution of a glutamine residue for an arginine in $\beta \mathrm{MHC}$ protein but to date transcription of a mutant $\beta$-myosin allele has not been demonstrated to occur in the tissue affected by this disease; namely, the myocardium. We used RT-PCR to examine the $\beta \mathrm{MHC}$ gene mRNA transcripts from a right ventricular endomyocardial biopsy obtained from the proband of Family 155 . Our results show that both the normal and mutant $\beta$ MHC alleles are transcribed as mRNA in this patient. This is the first demonstration of the transcription of a mutant $\beta \mathrm{MHC}$ gene mutation in the myocardium of a patient with hypertrophic cardiomyopathy. Rosenzweig et al. (16) have recently shown that a mutation in exon 9 of the $\beta M H C$ gene is transcribed into mRNA in lymphocytes. However, because most, if not all, genes in the human genome are thought to be transcribed at very low levels in lymphocytes, these results do not address whether these mutations are expressed in the pathologically relevant organ. It is perhaps less likely that the mRNA is significantly translated into protein in the lymphocyte, at least there is no priori reason for cardiac $\beta \mathrm{MHC}$ to be abundant or even present in lymphocytes. It may be argued that transcription of the mutant $\beta \mathrm{MHC}$ allele in myocardium is also the result of low level transcription similar to that detected by Rosenzweig et al. (16) in lymphocytes. However, in contrast to the lymphocyte, $\beta \mathrm{MHC}$ is the most abundant protein in the myocyte (24), thus the presence of the transcribed mutation in the mRNA is most likely to be expressed as protein. In addition to being transcribed in the organ responsible for the morphological and clinical manifestation of the disease, it is also of note that the amount of $\beta \mathrm{MHC}$ mutant mRNA in the myocardium appears to be in greater abundance than in the lymphocyte. We detected our $\beta$ MHC mutant mRNA in the myocardium after only 35 cycles of amplification in contrast to the 80 cycles of amplification required to detect mutant mRNA in the lymphocyte (16).

Because of the small size of Family 155, it is not possible by linkage studies to verify that the disease in this family is definitively linked to chromosome 14 . However, the compelling linkage data reported by Jarcho et al. (1) and Geisterfer-Lawrance et al. (6) for linkage to chromosome 14 and co-inheritance of the identical missense mutation in a large kindred make it unlikely that disease in Family 155 is not produced by the mutation. However, until the entire $\beta \mathrm{MHC}$ gene, including the sequences regulating gene expression are completely characterized, it is impossible to rule out the possibility of other mutations in the gene. The ultimate goal of unravelling the diverse pathophysiology of HCM now depends upon the isolation and functional characterization of the mutant $\beta \mathrm{MHC}$ protein and how it causes the disease.

Documentation that a mutation in $\beta \mathrm{MHC}$ gene is transcribed into cardiac mRNA in a patient affected with HCM is the first step in determining whether the defect, in $\beta \mathrm{MHC}$ gene, is responsible for this disease. This is of more than usual importance because, although the data linking the chromosomal locus of $14 \mathrm{q} 1$, the site of $\beta \mathrm{MHC}$ gene, is beyond question in the families showing such linkage, there are several reasons for concern over $\beta \mathrm{MHC}$ being the responsible gene. $\beta \mathrm{MHC}$ is the predominant form of myosin (35\% of myocyte proteins) in the human adult heart both in the right and left ventricles and is also present at the level of $10-15 \%$ in skeletal muscle. The 
lesion of HCM is essentially only present in the left ventricle and more importantly is localized in the majority of individuals to the septum. Why is it so localized, considering the myocardial abundance of distribution of $\beta \mathrm{MHC}$ ? Furthermore, studies on $\alpha$ - and $\beta$-myosin from patients affected with HCM by conventional biochemical techniques performed before the genetic studies have shown no abnormalities. Absolute documentation that the mutations in the $\beta \mathrm{MHC}$ gene are responsible for HCM may require many years as it has for most diseases in which the gene is identified through positional cloning (reverse genetics) such as dystrophin for Duchenne muscular dystrophy or the gene for cystic fibrosis. To encourage such studies and until the information is available, documentation that a mutant $\beta \mathrm{MHC}$ gene, which co-segregates with the disease, is indeed transcribed in the cardiac mRNA provides pivotal support until further enlightening scientific evidence is available. Cardiac growth and hypertrophy is the main adaptive response of the heart to all injuries and is universally present in cardiac failure. While it is expected that elucidation of the molecular defect will lead to better understanding, diagnosis and treatment of HCM it is also likely to shed light on cardiac growth and hypertrophy seen in response to injury. It would also represent the first defect for which the molecular basis has been determined for sudden death.

In the present study we made no attempt to relate our mutation to the pathophysiology or cause of this disease and thus, at this stage, one can only postulate potential mechanisms. In developing a model to account for mutations in $\beta \mathrm{MHC}$ gene, as responsible for this disease, one must first take into account the known obvious clinical findings that characterize this disease. Findings that are critical to development of any model include localized septal hypertrophy, increased myocardial contractility, increased rate of cardiac ejection, and decreased cardiac relaxation. It is also well recognized that the human ventricle of the patient with HCM has an abnormal emptying pattern being more complete than normal as well as taking on an unusual shape referred to as the hour glass phenomenon. We believe one model that can explain these findings would be that the particular mutation in $\beta \mathrm{MHC}$, incorporated into the myosin protein and thick filament of the sarcomere, imparts to the muscle the ability to increase its force and velocity contraction, which in turn will ultimately deform the geometry of the ventricle leading to an altered stress/strain relationship. In this mutation in which there is a substitution of glutamate for arginine there is an accompanying change in the ionic charge of $\beta \mathrm{MHC}$ from positive to negative, which may in some way alter the kinetics of its interaction with the actin-tropomyosin complex. It is well recognized that increased afterload leads to cardiac hypertrophy which is generally concentric in response to an homogeneous stimulus such as hypertension. The increased contractility induced by the mutant myosin is analogous to the stimulus of increased afterload, however, the response is asymmetrical since the altered stress/strain relationship within the ventricle impacts on the septum. We would not anticipate, necessarily, hypertrophy in the right ventricle since it is a low pressure volume chamber and workload is less than one quarter

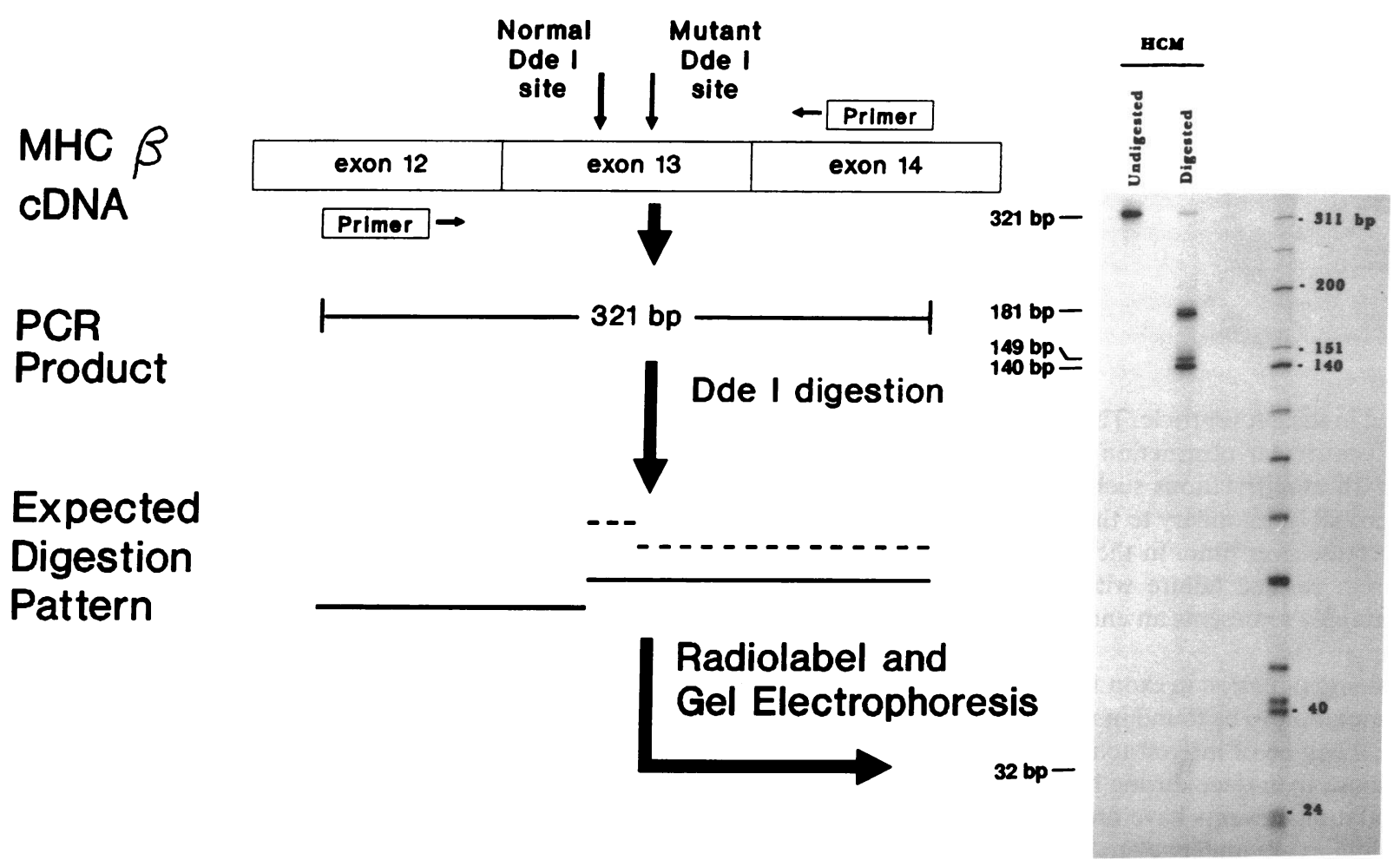

Figure 3. A schematic diagram of the relative locations of the normal and mutant Ddel restriction sites in exon 13 of the $\beta$ MHC cDNA is shown in the left portion of the figure. The 321-bp PCR product and the relative size of the nucleotide fragments produced after digestion of this product with Ddel also are depicted. An autoradiogram of an acrylamide gel of ${ }^{32} \mathrm{P}$-labeled Ddel endonuclease-digested cDNA fragments produced by RT-PCR of RNA isolated from an endomyocardial biopsy from the proband of Family 155 is shown in the right portion of this figure. The undigested PCR product is labeled Undigested and the Ddel-digested PCR product is labeled Digested. The undigested RT-PCR product is 321 bp in length and digestion with Ddel produces four fragments of $181,149,140$, and $32 \mathrm{bp}$. The molecular size markers are in the far right lane. 


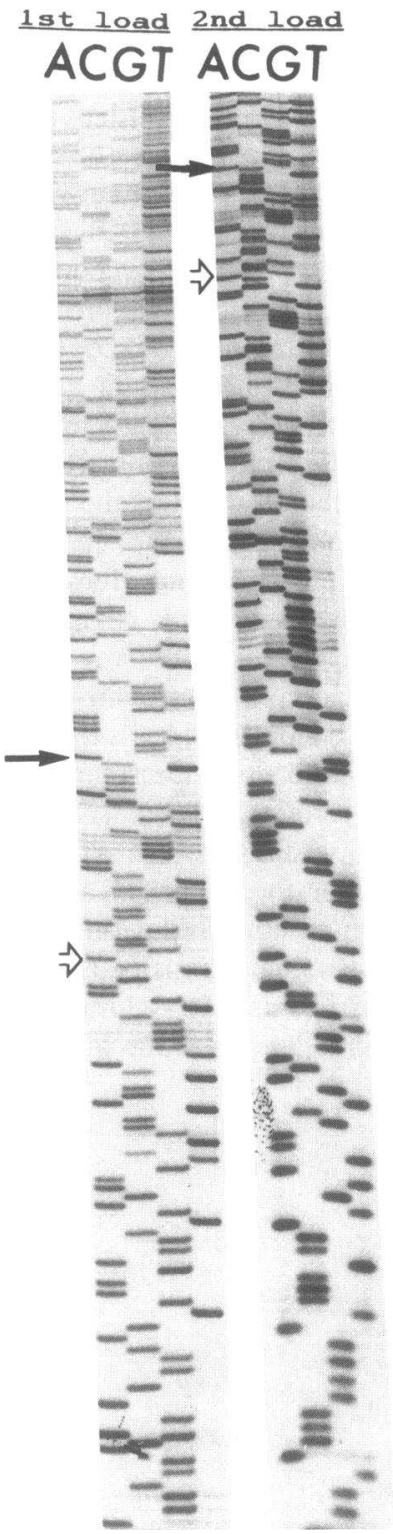

\section{I7}
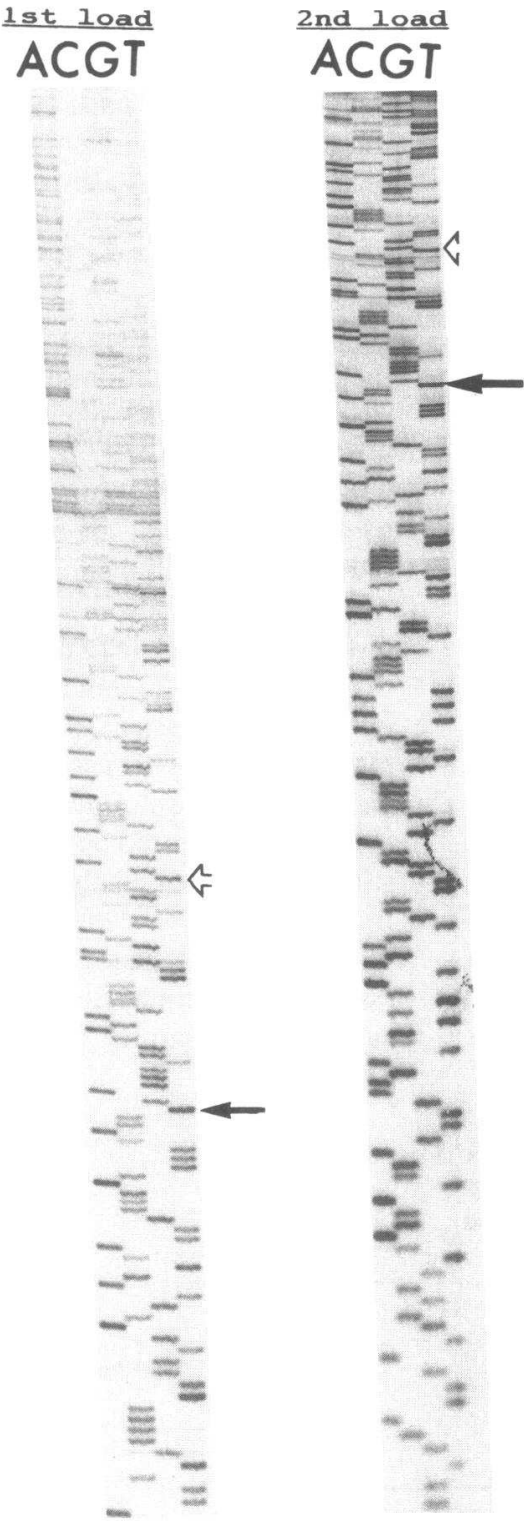

Figure 4. Sequence of the cloned PCR product amplified from cDNA segment encompassing exon 12-14 in the mutant allele of proband 155 . Substitution of $A$ for $G$ in the mutant allele creates an additional Ddel restriction site (CTCAG) indicated by the solid arrow $(\rightarrow)$. The normal Ddel restriction site is indicated by the open arrow. that observed in the left ventricle. The subsequent clinical findings of left ventricular obstruction or decreased compliance associated with manifestations such as dyspnea, angina, and failure are probably secondary to the hypertrophy which continues to increase over time. In the final stages of the disease one often sees cardiac failure with decreased contractility, which presumably represents an endstage secondary phenomenon.

The missense mutation in exon 13 of the $\beta \mathrm{MHC}$ gene is the first HCM mutation to be found in more than one family with the disease. It will be of interest to determine if this mutation has arisen more than once during human evolution or if two separate mutational events have produced the identical point mutation. Studies are underway to examine this question.

\section{Acknowledgments}

We greatly appreciate the expertise of Terry Tapscott in providing the DNA from the transformed lymphocytes and for the secretarial assistance of Debora H. Weaver and Alexandra Pinckard.
This work is supported in part by grants from the National Heart, Lung and Blood Institute, Specialized Centers of Research (P50HL42267-01), and the American Heart Association, Bugher Foundation Center for Molecular Biology (86-2216) and a grant for fellowship support (A. Mares, Jr., M.D.) from the Robert Wood Johnson Foundation (24-278223-974101).

\section{References}

1. Jarcho, J. A., W. P. McKenna, J. A. Pare, S. D. Solomon, R. F. Holcombe, S. Dickie, T. Levi, H. Donis-Keller, J. G. Seidman, and C. E. Seidman. 1989. Mapping a gene for familial hypertrophic cardiomyopathy to chromosome 14q1. N. Engl. J. Med. 321:1372-1378.

2. Hejtmancik, J. F., P. A. Brink, J. Towbin, R. Hill, L. Brink, T. Tapscott, A. Trakhtenbroit, and R. Roberts. 1991. Localization of gene for familial hypertrophic cardiomyopathy to chromosome $14 \mathrm{q} 1$ in a diverse U.S. population. Circulation. 83:1592-1597.

3. Solomon, S. D., A. A. T. Geisterfer-Lowrance, H.-P. Vosberg, G. Hiller, J. A. Jarcho, C. C. Morton, W. O. McBride, A. L. Mitchell, A. E. Bale, W. J. McKenna, et al. 1990. A locus for familial hypertrophic cardiomyopathy is closely linked to the cardiac myosin heavy genes, CR1-L436, and CRl-L329 on chromosome 14 at q11-912. Am. J. Hum. Genet. 47:389-394.

4. Matsuoka, R., M. C. Yoshida, N. Kanda, M. Kimura, H. Ozasa, and A. 
Takao. 1989. Human cardiac myosin heavy chain gene mapped within chromosome region 14q11.2-q13. Am. J. Med. Genet. 32:279-284.

5. Epstein, N. D., L. Fananapazir, H. J. Lin, J. Mulvihill, R. White, J. M. LaLouel, R. P. Lipton, A. W. Nunhuis, and M. Leppert. 1992. Evidence of genetic heterogeneity in five kindreds with familial hypertrophic cardiomyopathy. Circulation. 85:635-647.

6. Geisterfer-Lawrance, A. A., S. Kass, G. Tanigawa, H.-P. Vosberg, W. McKenna, C. E. Seidman, and J. G. Seidman. 1990. A molecular basis for familial hypertrophic cardiomyopathy: a beta-cardiac myosin heavy chain gene missense mutation. Cell. 62:999-1006.

7. Tanigawa, G., J. A. Jarcho, S. Kass, S. D. Solomon, and C. E. Seidman. 1990. A molecular basis for familial hypertrophic cardiomyopathy: An alpha/ beta cardiac myosin heavy chain hybrid gene. Cell. 62:991-998.

8. Watkins, H., D.-S. Hwang, A. Rosenzweig, G. Tanigawa, J. Jarcho, W. McKenna, J. G. Seidman, and S. Seidman. 1991. Analysis of cardiac myosin heavy chain gene mutations that cause familial hypertrophic cardiomyopathy. Circulation. 84(Suppl.):II418.

9. Perryman, M. B., A. Mares, Jr., F. Hejtmancik, G. Gooch, and R. Roberts. 1991. The $\beta$-myosin heavy chain missence mutation in exon 13 , a putative defect for HCM is present in only one of 39 families. Circulation 84:II-418. (Abstr)

10. Emerson, C. P., and S. I. Bernstein. 1987. Molecular genetics of myosin. Annu. Rev. Biochem. 56:695-726.

11. Saez, L. J., K. M. Gionala, E. M. McNally, R. Fegally, R. Eddy, T. B. Shows, and L. A. Lienward. 1987. Human cardiac myosin heavy chain genes and their linkage in the genome. Nucleic Acids Res. 15:5443-5459.

12. Maron, B. J., S. E. Epstein, and W. C. Roberts. 1986. Causes of sudden death in competitive athletes. J. Am. Coll. Cardiol. 7:204-214.

13. Maron, B. J., and W. C. Roberts. 1981. Hypertrophic cardiomyopathy and cardiac muscle cell disorganization revisited: relation between the two and significance. Am. Heart J. 102:95.

14. Schier, J. J., and R. S. Adelstein. 1982. Structural and enzymatic compari- son of human cardiac muscle myosins from infants, adults and patients with hypertrophic cardiomyopathy. J. Clin. Invest. 69:816-825.

15. Vybiral, T., R. Roberts, H. F. Epstein. 1991. Myofibrillar structure is intact in interventricular septal biopsies of hypertrophic cardiomyopathy linked to chromosome 14q1. Circulation. 84:II-419. (Abstr.)

16. Rosenzweig, A., H. Watkins, D. Hwang, M. Miri, W. McKenna, T. Traill, J. G. Seidman, and C. E. Seidman. 1991. Preclinical diagnosis of familial hypertrophic cardiomyopathy by genetic analysis of blood lymphocytes. $N$. Engl. J. Med. 325:1753-1760.

17. Neitzel, N. 1986. A routine method for the establishment of permanent growing lymphoblastoic cell lines. Hum. Genet. 73:320-326.

18. Lowe, T., J. Sharefkin, S. Q. Yang and C. W. Dieffenbach. 1990. A computer program for selection of oligonucleotide primers for polymerase chain reactions. Nucleic Acids Res. 18:1757-1761.

19. Liew, C. C., M. J. Sole, K. Yamauchi-Takihara, B. Kellam, D. H. Anderson, L. Lin, and J. C. Liew. 1990. Complete sequence and organization of the human cardiac beta-myosin heavy chain gene. Nucleic Acids Res. 18:3647-3651.

20. Chomczynski P: The RNAzol TM method. Cinna/Biotex Bull. No. 1 , 1988

21. Sambrook, J., E. F. Fritsch, and T. Maniatis. 1989. Construction and analysis of cDNA libraries. In Molecular Cloning: A Laboratory Manual. J. Sambrook, E. F. Fritsch, and T. Maniatis, editors. Cold Spring Harbor Press, Cold Spring Harbor, NY. 8.60-8.63.

22. Sambrook, J., E. F. Fritsch, and T. Maniatis. 1989. Preparation of readiolabeled DNA and RNA probes. In: Molecular Cloning: A Laboratory Manual. J. Sambrook, E. F. Fritsch, and T. Maniatis, editors. Cold Spring Harbor Press, Cold Spring Harbor, NY. 10.60-10.61.

23. Maron, B. J., P. Spirito, Y. Wesley, and J. Arce. 1986. Development and progression of left ventricular hypertrophy in children with hypertrophic cardiomyopathy. N. Engl. J. Med. 315:610-614.

24. Pollard, T. 1981. Cytoplasmic contractile proteins. J. Cell Biol. 91:156S. 